Article

\title{
Formation of Three-Dimensional Electronic Networks Using Axially Ligated Metal Phthalocyanines as Stable Neutral Radicals
}

\author{
Ryoya Sato and Masaki Matsuda *(C) \\ Department of Chemistry, Kumamoto University, 2-39-1 Kurokami, Kumamoto 860-8555, Japan; \\ 207d1308@st.kumamoto-u.ac.jp \\ * Correspondence: masaki@kumamoto-u.ac.jp
}

Received: 3 August 2020; Accepted: 21 August 2020; Published: 24 August 2020

check for updates

\begin{abstract}
Organic $\pi$-radical crystals are potential single-component molecular conductors, as they involve charge carriers. We fabricated new organic $\pi$-radical crystals using axially ligated metal phthalocyanine anions $\left(\left[\mathrm{M}^{\mathrm{III}}\left(\mathrm{Pc}_{\mathrm{C}}\right) \mathrm{L}_{2}\right]^{-}\right)$as starting materials. Electrochemical oxidation of $\left[\mathrm{M}^{\mathrm{III}}(\mathrm{Pc}) \mathrm{L}_{2}\right]^{-}$ afforded single crystals of organic $\pi$-radicals of the type $\mathrm{M}^{\mathrm{III}}(\mathrm{Pc}) \mathrm{Cl}_{2} \cdot \mathrm{THF}(\mathrm{M}=\mathrm{Co}$ or $\mathrm{Fe}$, $\mathrm{THF}=$ tetrahydrofuran), where the $\pi$-conjugated macrocyclic phthalocyanine ligand is one-electron oxidized. The X-ray crystal structure analysis revealed that $\mathrm{M}^{\mathrm{III}}\left(\mathrm{Pc}_{\mathrm{C}}\right) \mathrm{Cl}_{2}$ formed three-dimensional networks with $\pi$ - $\pi$ overlaps. The electrical resistivities of $\mathrm{Co}^{\mathrm{III}}(\mathrm{Pc}) \mathrm{Cl}_{2} \cdot \mathrm{THF}$ and $\mathrm{Fe}^{\mathrm{III}}(\mathrm{Pc}) \mathrm{Cl}_{2} \cdot \mathrm{THF}$ at room temperature along the $a$-axis were $6 \times 10^{2}$ and $6 \times 10^{3} \Omega \mathrm{cm}$, respectively, and were almost isotropic, meaning that $\mathrm{M}^{\mathrm{III}}(\mathrm{Pc}) \mathrm{Cl}_{2}$. THF had three-dimensional electronic systems.
\end{abstract}

Keywords: organic $\pi$-radical; molecular conductor; phthalocyanine; three-dimensional network; three-dimensional electronic system

\section{Introduction}

Ordinary organic radicals are unstable due to their high chemical reactivity, which is caused by the presence of an unpaired electron. However, organic radicals can be considered to have charge carriers, because their highest occupied molecular orbital (HOMO) is singly occupied, leading to a half-filled band in the solid state. Recently, a nonconjugated organic radical crystal has been reported to be conductive, although the conductivity is low in the solid state [1]. This might be due to the low degree of intermolecular overlap for the molecular orbital in which the radical lies. On the other hand, organic $\pi$-radicals tend to stack with significant overlap between adjacent molecules, giving rise to conducting pathways. For this reason, organic $\pi$-radicals have attracted significant interest from those studying molecular conductors, and it has been reported that despite the expected half-filled band, most organic $\pi$-radical crystals behave as Mott insulators because of the larger on-site Coulomb repulsion energy $(U)$ compared to the transfer energy $(t)[2,3]$. However, external changes such as pressure can control the competition between $U$ and $t$, leading to drastic phase transitions from the insulating state to metallic or superconducting states being reported for various molecular Mott insulators [3,4]. This means that if a stable neutral $\pi$-radical crystal is fabricated, it could be possible to obtain a single-component molecular conductor, which is a hot topic in the study of molecular crystals [5-9].

Axially ligated metal phthalocyanine anions $\left(\left[\mathrm{M}^{\mathrm{III}}(\mathrm{Pc}) \mathrm{L}_{2}\right]^{-}\right)$are attractive components for the construction of neutral $\pi$-radical crystals as single-component molecular conductors, because the wide $\pi$-conjugated system of phthalocyanine (Pc) might suppress $U$. Inabe expected that the electrochemical oxidation of the $\pi$-conjugated macrocyclic ligand in $\left[\mathrm{M}^{\mathrm{III}}(\mathrm{Pc}) \mathrm{L}_{2}\right]^{-}$would give rise to conducting crystals, 
while the $\mathrm{M}^{\mathrm{III}}(\mathrm{Pc}) \mathrm{L}_{2}$ unit could impart many kinds of dimensionality to the molecular arrangement as the axial ligand induces slipped stacks (Figure 1) [10]. Indeed, it was found that there were two different types of $\pi-\pi$ overlaps between the $\mathrm{M}^{\mathrm{III}}(\mathrm{Pc}) \mathrm{L}_{2}$ units (Figure 2 ). Although the $\pi-\pi$ overlaps are significantly reduced compared to those seen in $\mathrm{M}(\mathrm{Pc}) X$-type conductors having face-to-face stacking (the overlap integral of type $\mathrm{A}$ is about $40 \%$ of that of $\mathrm{M}(\mathrm{Pc}) \mathrm{X}$-type conductors) [11], it is enough for electrical conduction. Consequently, a large number of molecular conducting crystals composed of $\mathrm{M}^{\mathrm{III}}(\mathrm{Pc}) \mathrm{L}_{2}$ units were fabricated, including $\pi$-neutral radical crystals as well as crystals of highly conducting partially oxidized salts, with molecular arrangements showing the formation of one-dimensional, two-dimensional, and also three-dimensional networks [12-14]. Although all $\pi$-neutral radical crystals composed of $\mathrm{M}^{\mathrm{III}}(\mathrm{Pc}) \mathrm{L}_{2}$ are Mott insulators, their resistivities are relatively small.

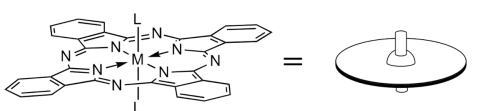

(b)

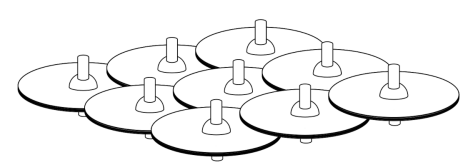

(a)

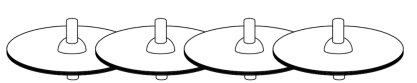

(c)

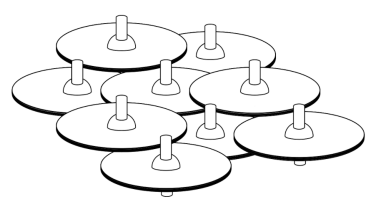

Figure 1. Possible dimensionalities of the molecular arrangements induced by slipped stacking of $\mathrm{M}^{\mathrm{III}}(\mathrm{Pc}) \mathrm{L}_{2}$ : (a) one-dimensional arrangement, (b) two-dimensional arrangement, and (c) three-dimensional arrangement.

(a) Type A

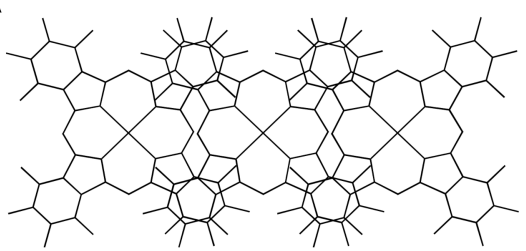

(b) Type B

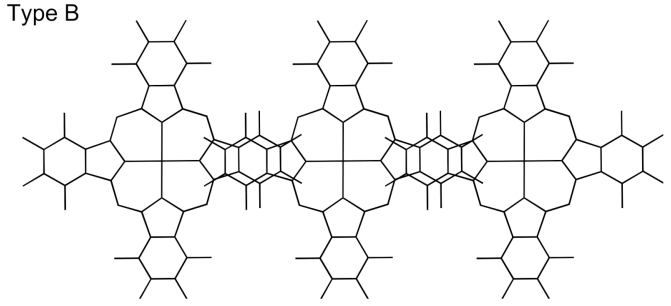

Figure 2. Two types of $\pi-\pi$ overlaps between the $\mathrm{M}^{\mathrm{III}}(\mathrm{Pc}) \mathrm{L}_{2}$ units: (a) overlap involving two peripheral benzene rings per unit (type A); (b) overlap involving one peripheral benzene ring per unit (type B).

Herein, we focused on the dimensionality of $\mathrm{M}^{\mathrm{III}}(\mathrm{Pc}) \mathrm{L}_{2}$ crystals. It has been reported that the conductivity of $\mathrm{M}^{\mathrm{III}}(\mathrm{Pc}) \mathrm{L}_{2}$ radical crystals tends to increase as the dimensionality of the network is increased [14]; the first example of a three-dimensional neutral radical crystal of $\mathrm{Co} \mathrm{OII}^{\mathrm{II}}(\mathrm{Pc})(\mathrm{CN})_{2} \cdot 2 \mathrm{H}_{2} \mathrm{O}$ exhibited a resistivity at room temperature of no more than $10^{0} \Omega \mathrm{cm}$ with an activation energy of less than $0.1 \mathrm{eV}$ [10]. However, only a few examples of three-dimensional systems exist at present [14]. We have fabricated a new three-dimensional system consisting of neutral radical crystals of $\mathrm{M}^{\mathrm{III}}(\mathrm{Pc}) \mathrm{Cl}_{2} \cdot \mathrm{THF}(\mathrm{M}=\mathrm{Co}$ or $\mathrm{Fe}, \mathrm{THF}=$ tetrahydrofuran). In this paper, the crystal structures and electrical properties of $\mathrm{M}^{\mathrm{III}}\left(\mathrm{Pc}_{\mathrm{C}}\right) \mathrm{Cl}_{2} \cdot \mathrm{THF}$ are reported. 


\section{Materials and Methods}

\subsection{Materials}

$\mathrm{Co}^{\mathrm{II}}(\mathrm{Pc})$ and $\mathrm{Fe}^{\mathrm{II}}(\mathrm{Pc})$ were prepared by refluxing $\mathrm{CoCl}_{2} \cdot 6 \mathrm{H}_{2} \mathrm{O}$ or $\mathrm{FeCl}_{2} \cdot 4 \mathrm{H}_{2} \mathrm{O}$ with four molar equivalents of 1,2-dicyanobenzene in quinoline, and $\mathrm{Co}^{\mathrm{II}}(\mathrm{Pc})$ or $\mathrm{Fe}^{\mathrm{II}}(\mathrm{Pc})(3.0 \mathrm{~g}, 5.2 \mathrm{mmol})$ was treated with $\mathrm{SOCl}_{2}(5 \mathrm{~mL}, 69 \mathrm{mmol})$ in nitrobenzene $(70 \mathrm{~mL})$ at $70{ }^{\circ} \mathrm{C}$ for $6 \mathrm{~h}$ to produce $\mathrm{Co}{ }^{\mathrm{III}}(\mathrm{Pc}) \mathrm{Cl}_{2}$ (yield $3.2 \mathrm{~g}$, $5.0 \mathrm{mmol}, 95 \%$ ) or $\mathrm{Fe}^{\mathrm{III}}(\mathrm{Pc}) \mathrm{Cl}_{2}$ (yield $\left.2.1 \mathrm{~g}, 3.3 \mathrm{mmol}, 62 \%\right)[15,16]$. Then, $\mathrm{K}\left[\mathrm{M}^{\mathrm{III}}(\mathrm{Pc})(\mathrm{SCN})_{2}\right]$ was prepared according to the literature [16,17], by reacting $\mathrm{M}^{\mathrm{III}}(\mathrm{Pc}) \mathrm{Cl}_{2}(2.0 \mathrm{~g}, 3.1 \mathrm{mmol})$ with $\mathrm{KSCN}(6.0 \mathrm{~g}$, $62 \mathrm{mmol}$ ) in acetone $\left(200 \mathrm{~mL}\right.$ ) at $25^{\circ} \mathrm{C}$ for $48 \mathrm{~h}$ (yield $2.1 \mathrm{~g}, 2.9 \mathrm{mmol}, 94 \%$ ).

Electrochemical oxidation of $\mathrm{K}\left[\mathrm{M}^{\mathrm{III}}(\mathrm{Pc})(\mathrm{SCN})_{2}\right](30 \mathrm{mg})$ with two equivalents of tetraethylammonium chloride or tetrabutylammonium chloride was performed under a constant current of $1 \mu \mathrm{A}$ in a THF:acetonitrile $(30 \mathrm{~mL}, 1: 1 \mathrm{v} / \mathrm{v})$ solution at $25^{\circ} \mathrm{C}$ using an electrocrystallization cell equipped with a glass frit between the two compartments, and yielded black square-pillar crystals of $\mathrm{M}^{\mathrm{III}}(\mathrm{Pc}) \mathrm{Cl}_{2}$.THF on the anode. The typical size of the crystals obtained was between $0.5 \times 0.3 \times 0.3 \mathrm{~mm}^{3}$ and $1.0 \times 0.5 \times 0.5 \mathrm{~mm}^{3}$. The obtained radical crystals were stable, and no decomposition was detected in the X-ray crystal structures or electrical resistivity measurements over several months. The Schematic route for the synthesis is shown in Figure 3.

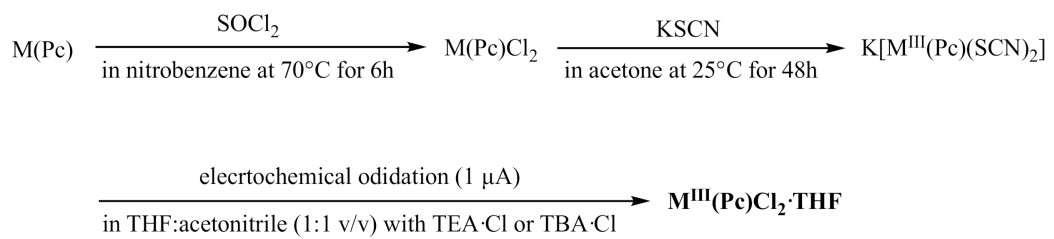

Figure 3. Schematic route for the synthesis of single crystals of $\mathrm{M}^{\mathrm{III}}\left(\mathrm{Pc}_{\mathrm{C}}\right) \mathrm{Cl}_{2} \cdot \mathrm{THF}$.

\subsection{X-ray Crystal Structure Determination}

Crystal data for $\mathrm{M}\left(\mathrm{Pc}_{\mathrm{c}}\right) \mathrm{Cl}_{2}$. THF were collected at $298 \mathrm{~K}$ using an automated Rigaku SuperNova system (Rigaku, Tokyo, Japan) with monochromated Mo-K $\alpha$ radiation $(\lambda=0.71073 \AA)$. The structure was solved by using SIR2019 [18,19], and was refined by a full-matrix least-squares technique with SHELXL-2018/1 [20] using anisotropic and isotropic thermal parameters for non-hydrogen and hydrogen atoms, respectively. Orientational disorder was observed for the solvent site (THF molecule). We assigned $\mathrm{C}$ and $\mathrm{O}$ atoms according to the bond lengths.

Crystal data for $\mathrm{Co}\left(\mathrm{Pc}_{\mathrm{C}} \mathrm{Cl}_{2} \cdot \mathrm{THF}\right.$ at $298 \mathrm{~K}$ : Formula, $\mathrm{C}_{36} \mathrm{H}_{24} \mathrm{Cl}_{2} \mathrm{CoN}_{8} \mathrm{O}$, Formula weight 714.46, monoclinic, $P 22_{1} / n$ (\#14), $a=8.2526(2), b=15.4184(6) \AA, c=11.8762(4) \AA, \beta=92.996(3)^{\circ}, V=1509.08(9) \AA^{3}$, $\mathrm{Z}=2, d_{\mathrm{cal}}=1.572 \mathrm{~g} \mathrm{~cm}^{-3}, \mu(\mathrm{MoK} \alpha)=0.793 \mathrm{~mm}^{-1}(\lambda=0.71073 \AA), R_{1}=0.0545, \mathrm{w} R_{2}=0.1852, \mathrm{GoF}=1.280$. CCDC 2013803.

Crystal data for $\mathrm{Fe}(\mathrm{Pc}) \mathrm{Cl}_{2}$. THF at $298 \mathrm{~K}$ : Formula, $\mathrm{C}_{36} \mathrm{H}_{24} \mathrm{Cl}_{2} \mathrm{FeN}_{8} \mathrm{O}$, Formula weight 711.38, monoclinic, $P 21 / n$ (\#14), $a=8.2062(1), b=15.4115(1) \AA, c=11.9043(1) \AA, \beta=93.2238(9)^{\circ}$, $V=1503.15(2) \AA^{3}, Z=2, d_{\text {cal }}=1.572 \mathrm{~g} \mathrm{~cm}^{-3}, \mu(\mathrm{MoK} \alpha)=0.727 \mathrm{~mm}^{-1}(\lambda=0.71073 \AA), R_{1}=0.0435$, $\mathrm{w} R_{2}=0.1797, \mathrm{GoF}=1.503$. CCDC 2013804 .

CCDC 2013803 and 2013804 contain the supplementary crystallographic data for this paper. These data can be obtained free of charge via http://www.ccdc.cam.ac.uk/conts/retrieving. html (or from the CCDC, 12 Union Road, Cambridge CB2 1EZ, UK; Fax: +44-1223-336033; E-mail: deposit@ccdc.cam.ac.uk).

Extended Hückel calculations were performed using a CAESAR 2 software package (Prime Color Software, Inc., Charlotte, NC, USA) with the atomic parameters determined by the X-ray structure analysis. Default parameters were used. 


\subsection{Measurements}

Electrical resistivity measurements along the $a$-axis of $\mathrm{M}^{\mathrm{III}}(\mathrm{Pc}) \mathrm{Cl}_{2} \cdot \mathrm{THF}$ single crystals were performed by the standard four-probe method. The two-probe method was also adopted for the measurement with the current parallel and perpendicular to the $a$-axis. The electrical leads, which were gold wires with diameters of $25 \mu \mathrm{m}$, were attached to the crystal face using gold paste (Figure 4). The data are typical, as the resistivity and activation energies varied slightly depending on the individual crystal examined. However, we confirmed the reproducibility of the data by examining several crystals of both materials.

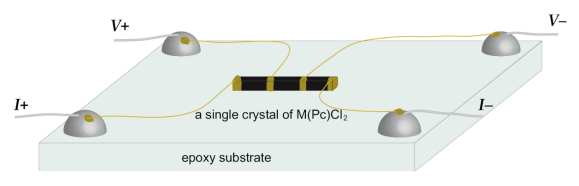

Figure 4. Schematic of the electrical resistivity measurements. Four or two gold wires were attached to a single crystal using gold paste.

\section{Results}

$\mathrm{Co}^{\mathrm{III}}(\mathrm{Pc}) \mathrm{Cl}_{2} \cdot \mathrm{THF}$ and $\mathrm{Fe}^{\mathrm{III}}(\mathrm{Pc}) \mathrm{Cl}_{2} \cdot \mathrm{THF}$ were found to have a monoclinic unit cell with the $P 2_{1} / n$ space group, and were isostructural to each other (Table 1). Similar isostructural natures have been reported for $\mathrm{M}\left(\mathrm{Pc}_{\mathrm{C}}\right) \mathrm{L}_{2}$-based conductors [21-23], because the rigid geometry of the Pc framework is insensitive to the central ion. Figure 5 shows the crystal structure of $\mathrm{Co}^{\mathrm{III}}\left(\mathrm{Pc}_{\mathrm{C}} \mathrm{Cl}_{2} \cdot \mathrm{THF}\right.$. Because the oxidation potentials of $\mathrm{Co}^{\mathrm{III}}$ and $\mathrm{Fe}^{\mathrm{III}}$ are higher than that of $\mathrm{Pc}^{2-}[10,24]$, the Pc ligand is oxidized to $\mathrm{Pc}^{\bullet-}$, meaning $\mathrm{M}^{\mathrm{III}}(\mathrm{Pc}) \mathrm{Cl}_{2} \cdot \mathrm{THF}$ is a neutral $\pi$-radical. The $\mathrm{M}^{\mathrm{III}}(\mathrm{Pc}) \mathrm{Cl}_{2}$ units form one-dimensional stacks along the $a$-axis via interactions between two peripheral benzene rings per unit, with interplanar distances of 3.49 and $3.54 \AA$ (type A), and also form additional stacks along the [11 $\overline{1}]$ and [1 $\overline{11}]$ directions with one peripheral benzene ring per unit (type B) with interplanar distances of 3.43 and $3.44 \AA$, respectively, resulting in the formation of three-dimensional networks. To evaluate the effectiveness of the stacking, the overlap integrals between the HOMOs of adjacent Pcs along each stacking direction were calculated by the extended Hückel method based on the structural data (Table 2). Because the intermolecular overlap integral is usually regarded as being proportional to transfer energy, the estimation of the overlap integrals can be a useful index for investigating the anisotropies of molecular stacks [25], and it was found that the overlap integrals along the $a$-axis of type A stacks were almost twice those seen in other stacks.

Table 1. Crystal data of $\mathrm{CO}^{\mathrm{III}}\left(\mathrm{Pc}_{\mathrm{C}}\right) \mathrm{Cl}_{2} \cdot \mathrm{THF}$ and $\mathrm{Fe}^{\mathrm{III}}\left(\mathrm{Pc}_{\mathrm{C}}\right) \mathrm{Cl}_{2} \cdot \mathrm{THF}$.

\begin{tabular}{ccc}
\hline & $\mathbf{C o}{ }^{\mathrm{III}}(\mathbf{P c}) \mathbf{C l}_{2} \cdot \mathbf{T H F}$ & $\mathbf{F e}^{\mathrm{III}}\left(\mathbf{P c}_{\mathbf{c}}\right) \mathbf{C l}_{2} \cdot \mathbf{T H F}$ \\
\hline Space Group & $P 2_{1} / n$ & $P 2_{1} / n$ \\
$a(\AA)$ & $8.2526(2)$ & $8.2062(1)$ \\
$b(\AA)$ & $15.4184(6)$ & $15.4115(1)$ \\
$c(\AA)$ & $11.8762(4)$ & $11.9043(1)$ \\
$\beta\left({ }^{\circ}\right)$ & $92.996(3)$ & $92.2238(9)$ \\
Volume $\left(\AA^{3}\right)$ & $1509.08(9)$ & $1503.15(2)$ \\
Temperature $(\mathrm{K})$ & 298 & 298 \\
CCDC & 2013803 & 2013804 \\
\hline
\end{tabular}

Figure 6 shows the temperature dependences of the electrical resistivities along the $a$-axes of $\mathrm{Co}^{\mathrm{III}}\left(\mathrm{Pc}_{2}\right) \mathrm{Cl}_{2} \cdot \mathrm{THF}$ and $\mathrm{Fe}^{\mathrm{III}}(\mathrm{Pc}) \mathrm{Cl}_{2} \cdot \mathrm{THF}$. The electrical resistivities of $\mathrm{Co}^{\mathrm{III}}(\mathrm{Pc}) \mathrm{Cl}_{2} \cdot \mathrm{THF}$ and $\mathrm{Fe}^{\mathrm{III}}(\mathrm{Pc}) \mathrm{Cl}_{2} \cdot \mathrm{THF}$ at room temperature were $6.3 \times 10^{2}$ and $6.1 \times 10^{3} \Omega \mathrm{cm}$, respectively, and both systems showed semi-conducting behavior, with activation energies of $0.20 \mathrm{eV}$ for $\mathrm{Co}{ }^{\mathrm{III}}\left(\mathrm{Pc}_{\mathrm{C}}\right) \mathrm{Cl}_{2} \cdot \mathrm{THF}$ and $0.24 \mathrm{eV}$ for $\mathrm{Fe}^{\mathrm{III}}(\mathrm{Pc}) \mathrm{Cl}_{2} \cdot \mathrm{THF}$. 
(a)
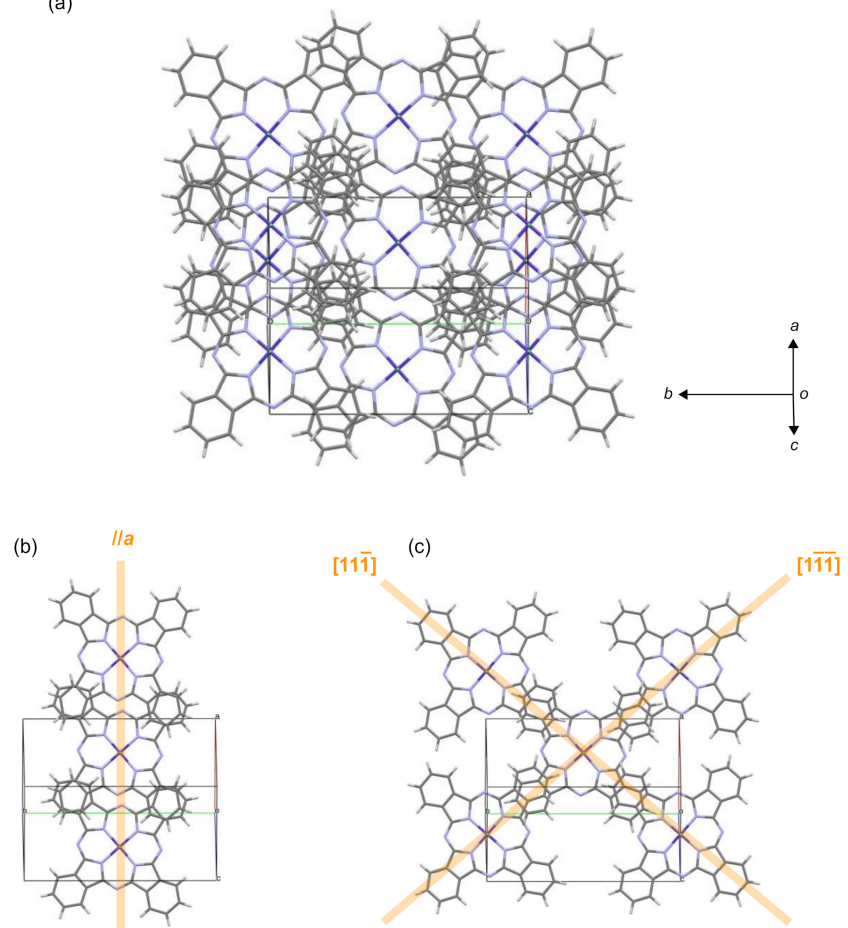

Figure 5. Crystal structure of $\mathrm{Co}^{\mathrm{III}}\left(\mathrm{Pc}_{\mathrm{C}}\right) \mathrm{Cl}_{2}$.THF: (a) view perpendicular to Pc plane, (b) molecular arrangement along the $a$-axis, and (c) molecular arrangement along [11 $\overline{1}]$ and [1 $\overline{11}]$ directions. Tetrahydrofuran (THF) molecules have been omitted for clarity.

Table 2. Overlap integrals between HOMOs of adjacent Pcs in $\mathrm{M}^{\mathrm{III}}\left(\mathrm{Pc}_{\mathrm{C}} \mathrm{Cl}_{2} \cdot \mathrm{THF}\right.$.

\begin{tabular}{lcccc}
\hline & & $\begin{array}{c}\text { [100] } \\
\text { with Type A }\end{array}$ & $\begin{array}{c}{[\mathbf{1 1 1}]} \\
\text { with Type B }\end{array}$ & $\begin{array}{c}{[\mathbf{1 1 1}]} \\
\text { with Type B }\end{array}$ \\
\hline \multirow{2}{*}{$\mathrm{Co}^{\mathrm{III}}(\mathrm{Pc}) \mathrm{Cl}_{2} \cdot \mathrm{THF}$} & Overlap Integral & $2.0 \times 10^{-3}$ & $0.9 \times 10^{-3}$ & $0.9 \times 10^{-3}$ \\
\multirow{2}{*}{$\mathrm{Fe}^{\mathrm{III}}(\mathrm{Pc}) \mathrm{Cl}_{2} \cdot \mathrm{THF}$} & Interplanar Distance $(\AA)$ & $3.49,3.54$ & 3.43 & 3.44 \\
& Overlap Integral & $2.3 \times 10^{-3}$ & $0.9 \times 10^{-3}$ & $0.9 \times 10^{-3}$ \\
& Interplanar Distance $(\AA)$ & $3.49,3.54$ & 3.42 & 3.43 \\
\hline
\end{tabular}

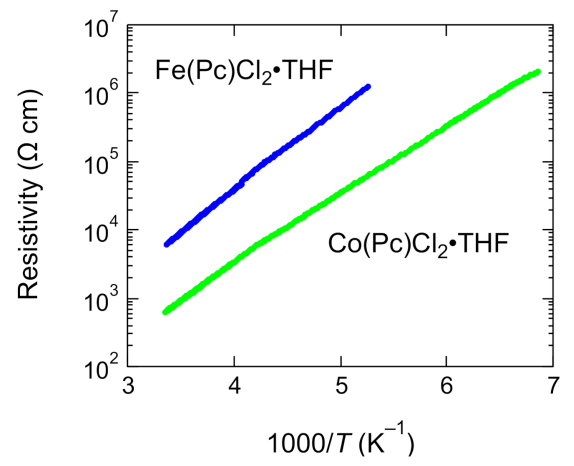

Figure 6. Temperature dependence of the electrical resistivities of $\mathrm{Co}^{\mathrm{III}}\left(\mathrm{Pc}_{\mathrm{C}}\right) \mathrm{Cl}_{2} \cdot \mathrm{THF}$ (green) and $\mathrm{Fe}^{\mathrm{III}}(\mathrm{Pc}) \mathrm{Cl}_{2} \cdot \mathrm{THF}$ (blue) along the $a$-axis, measured by the standard four-probe method.

Figure 7 shows the temperature dependences of the electrical resistivities of $\mathrm{Co}^{\mathrm{III}}(\mathrm{Pc}) \mathrm{Cl}_{2} \cdot \mathrm{THF}$ and $\mathrm{Fe}^{\mathrm{III}}(\mathrm{Pc}) \mathrm{Cl}_{2} \cdot \mathrm{THF}$ along the $a$-axis $(/ / a)$ and perpendicular to the $a$-axis $(\perp a)$, as measured by the two-probe method. In both systems, the resistivity along the $a$-axis was smaller than that perpendicular to the $a$-axis, reflecting the difference in the overlap integrals; however, the current-direction dependence of the 
electrical resistivity was less than one order of magnitude. The activation energies of $\mathrm{Co}^{\mathrm{III}}\left(\mathrm{Pc}_{\mathrm{C}}\right) \mathrm{Cl}_{2} \cdot \mathrm{THF}$ and $\mathrm{Fe}^{\mathrm{III}}(\mathrm{Pc}) \mathrm{Cl}_{2} \cdot \mathrm{THF}$ were almost independent of the direction of conduction.
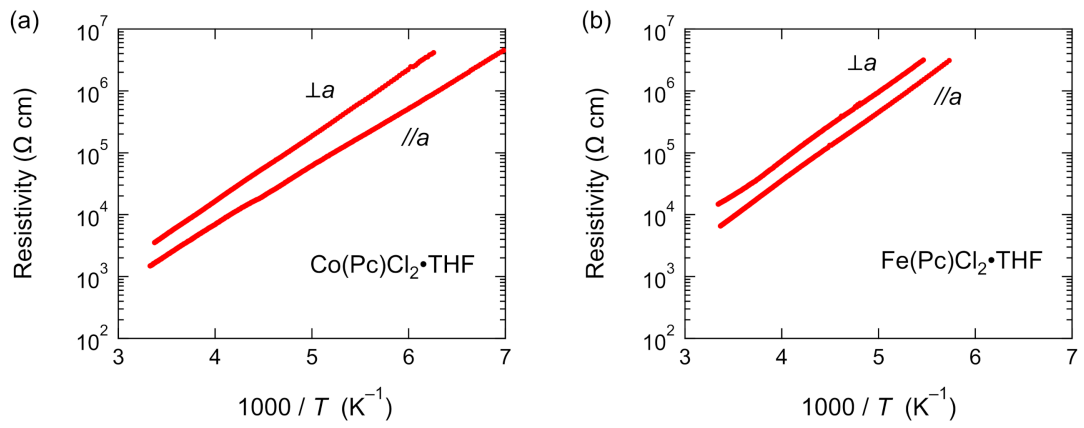

Figure 7. Temperature dependences of the electrical resistivities of (a) $\mathrm{Co}^{\mathrm{III}}(\mathrm{Pc}) \mathrm{Cl}_{2} \cdot \mathrm{THF}$ and (b) $\mathrm{Fe}^{\mathrm{III}}(\mathrm{Pc}) \mathrm{Cl}_{2} \cdot \mathrm{THF}$ along the $a$-axis $(/ / a)$ and perpendicular to the $a$-axis $(\perp a)$, as measured by the two-probe method.

\section{Discussions}

Despite the isostructural nature of the two compounds, the electrical resistivity of $\mathrm{Fe}{ }^{\mathrm{III}}\left(\mathrm{Pc}_{\mathrm{C}}\right) \mathrm{Cl}_{2} \cdot \mathrm{THF}$ was almost one order of magnitude higher than that of $\mathrm{Co}{ }^{\mathrm{III}}(\mathrm{Pc}) \mathrm{Cl}_{2} \cdot \mathrm{THF}$, and the activation energy was also higher. Similar enhancements of the electrical resistivity and activation energy have been reported for molecular conductors based on $\mathrm{M}^{\mathrm{III}}(\mathrm{Pc}) \mathrm{L}_{2}$ [21-23], and could be attributable to the different magnetic moments of the central metal ions. Low-spin Fe ${ }^{\mathrm{III}}$ has a magnetic moment of $S=1 / 2$, while low-spin $\mathrm{Co}^{\mathrm{III}}$ has no magnetic moment $(S=0)$, and it has been reported that the magnetic moment enhances the electrical resistivity [26].

As shown in Figure 7, the electrical resistivity of $\mathrm{M}^{\mathrm{III}}\left(\mathrm{Pc}_{2}\right) \mathrm{Cl}_{2} \cdot \mathrm{THF}$ depended on the current direction; however, the difference was quite small. In one- or two-dimensional systems, the resistivity along the stacking direction(s) was two orders of magnitude smaller than that perpendicular to the stacking direction(s) [27]. Therefore, the almost isotropic nature observed in the resistivity measurements in this study demonstrates that $\mathrm{M}^{\mathrm{III}}\left(\mathrm{Pc}_{\mathrm{C}}\right) \mathrm{Cl}_{2}$. THF had a three-dimensional electronic system. However, the electrical resistivity of $\mathrm{Co}^{\mathrm{III}}(\mathrm{Pc}) \mathrm{Cl}_{2} \cdot \mathrm{THF}$ at room temperature $\left(6.3 \times 10^{2} \Omega \mathrm{cm}\right)$ was two orders of magnitude higher than that of $\mathrm{Co}^{\mathrm{III}}(\mathrm{Pc})(\mathrm{CN})_{2} \cdot 2 \mathrm{H}_{2} \mathrm{O}$, which was the first example of a three-dimensional neutral $\pi$-radical crystal of the type $\mathrm{M}^{\mathrm{III}}(\mathrm{Pc}) \mathrm{L}_{2}$ [10]. The activation energy of $\mathrm{M}^{\mathrm{III}}(\mathrm{Pc}) \mathrm{Cl}_{2} \cdot \mathrm{THF}$ was also higher than that of $\mathrm{Co}{ }^{\mathrm{III}}(\mathrm{Pc})(\mathrm{CN})_{2} \cdot 2 \mathrm{H}_{2} \mathrm{O}$. Therefore, we calculated the overlap integrals of $\mathrm{Co}^{\mathrm{III}}(\mathrm{Pc})(\mathrm{CN})_{2} \cdot 2 \mathrm{H}_{2} \mathrm{O}$ based on the reported crystal data, and compared the results with the overlap integrals of $\mathrm{CO}^{\mathrm{III}}(\mathrm{Pc}) \mathrm{Cl}_{2} \cdot \mathrm{THF}$ (Table 3). Although the molecular arrangement of $\mathrm{M}^{\mathrm{III}}(\mathrm{Pc}) \mathrm{Cl}_{2}$ in $\mathrm{M}^{\mathrm{III}}(\mathrm{Pc}) \mathrm{Cl}_{2} \cdot \mathrm{THF}$ appeared to be similar to that of $\mathrm{Co}^{\mathrm{III}}(\mathrm{Pc})(\mathrm{CN})_{2}$ in $\mathrm{Co}^{\mathrm{III}}(\mathrm{Pc})(\mathrm{CN})_{2} \cdot 2 \mathrm{H}_{2} \mathrm{O}$, the overlap integrals of $\mathrm{Co}^{\mathrm{III}}(\mathrm{Pc})(\mathrm{CN})_{2} \cdot 2 \mathrm{H}_{2} \mathrm{O}$ were quite different from those of $\mathrm{M}^{\mathrm{III}}(\mathrm{Pc}) \mathrm{Cl}_{2} \cdot \mathrm{THF}$. The overlap integral along the $c$-axis, where $\mathrm{Co}{ }^{\mathrm{III}}(\mathrm{Pc})(\mathrm{CN})_{2}$ formed a type A one-dimensional stack, was $5.7 \times 10^{-3}$, while the overlap integrals along the [112] and [11̄2] directions, where $\mathrm{Co}{ }^{\mathrm{III}}(\mathrm{Pc})(\mathrm{CN})_{2}$ formed type B stacks, were $1.7 \times 10^{-3}$. These values were more than twice those obtained for $\mathrm{Co}^{\mathrm{III}}\left(\mathrm{Pc}_{\mathrm{C}}\right) \mathrm{Cl}_{2} \cdot \mathrm{THF}$. These discrepancies could be the cause of the difference in the electrical properties, meaning that slight changes in molecular arrangements could lead to drastic changes in the electrical properties in the neutral $\pi$-radical crystals composed of $\mathrm{M}^{\mathrm{III}}(\mathrm{Pc}) \mathrm{L}_{2}$.

Table 3. Comparison of the overlap integrals between similar three-dimensional systems of $\mathrm{Co}^{\mathrm{III}}(\mathrm{Pc}) \mathrm{Cl}_{2} \cdot \mathrm{THF}$ and $\mathrm{Co}^{\mathrm{III}}(\mathrm{Pc})(\mathrm{CN})_{2} \cdot 2 \mathrm{H}_{2} \mathrm{O}$.

\begin{tabular}{ccc}
\hline & with Type A & with Type B \\
\hline $\mathrm{Co}^{\mathrm{III}}(\mathrm{Pc}) \mathrm{Cl}_{2} \cdot \mathrm{THF}$ & $2.0 \times 10^{-3}$ & $0.9 \times 10^{-3}$ \\
$\mathrm{Co}^{\mathrm{III}}(\mathrm{Pc})(\mathrm{CN})_{2} \cdot \mathrm{H}_{2} \mathrm{O}$ & $5.7 \times 10^{-3}$ & $1.7 \times 10^{-3}$ \\
\hline
\end{tabular}




\section{Conclusions}

We succeeded in fabricating single crystals of stable organic $\pi$-radicals of the type $\mathrm{M}^{\mathrm{III}}\left(\mathrm{Pc}_{\mathrm{c}}\right) \mathrm{Cl}_{2} \cdot \mathrm{THF}$ $(\mathrm{M}=\mathrm{Co}$ or $\mathrm{Fe}, \mathrm{THF}=$ tetrahydrofuran). The overlap integrals between the HOMOs of adjacent Pcs were calculated based on the atomic parameters determined by the X-ray crystal structural analyses, and it was revealed that $\mathrm{M}^{\mathrm{III}}(\mathrm{Pc}) \mathrm{Cl}_{2}$ formed three-dimensional networks. Furthermore, the electrical resistivities measured were almost independent of the applied current direction, meaning that $\mathrm{M}^{\mathrm{III}}(\mathrm{Pc}) \mathrm{Cl}_{2} \cdot \mathrm{THF}$ had three-dimensional electronic systems, which are rarely observed in the study of molecular conductors. The resistivities of $\mathrm{Co}^{\mathrm{III}}\left(\mathrm{Pc}_{\mathrm{C}} \mathrm{Cl}_{2} \cdot \mathrm{THF}\right.$ and $\mathrm{Fe}^{\mathrm{III}}(\mathrm{Pc}) \mathrm{Cl}_{2} \cdot \mathrm{THF}$ at room temperature were $6 \times 10^{2}$ and $6 \times 10^{3} \Omega \mathrm{cm}$, respectively. These are similar to or significantly smaller than those reported for neutral radical conductors showing pressure-induced metallization $[6,8]$, indicating that further study of three-dimensional Mott insulators composed of $\mathrm{M}^{\mathrm{III}}(\mathrm{Pc}) \mathrm{L}_{2}$ under the application of pressure could allow for phase transitions from insulating to metallic or superconducting states. Furthermore, it was revealed that a slight change in molecular arrangement led to drastic changes in the electrical properties. As $\mathrm{M}^{\mathrm{III}}(\mathrm{Pc}) \mathrm{L}_{2}$ shows various stacking types depending on the fabrication conditions, there is a strong possibility that new single-component molecular conductors composed of $\mathrm{M}^{\mathrm{III}}(\mathrm{Pc}) \mathrm{L}_{2}$ could be produced.

Author Contributions: Conceptualization, R.S. and M.M.; methodology, R.S.; software, R.S.; formal analysis, M.M.; writing —original draft preparation, M.M.; writing—review and editing, R.S. and M.M.; visualization, M.M.; supervision, M.M.; project administration, M.M.; funding acquisition, M.M. All authors have read and agreed to the published version of the manuscript.

Funding: This research was funded by a Grant-in-Aid for Scientific Research (B), grant number 19H02691, from the Japan Society for the Promotion of Science.

Acknowledgments: We dedicate this study to Tamotsu Inabe. We thank Akira Yoshiasa at Kumamoto University for his help with the X-ray diffraction measurements.

Conflicts of Interest: The authors declare no conflict of interest.

\section{References}

1. Yu, I.; Jo, Y.; Ko, J.; Kim, D.-Y.; Sohn, D.; Joo, Y. Making nonconjugated small-molecule organic radicals conduct. Nano Lett. 2020, 20, 5376-5382. [CrossRef] [PubMed]

2. Jérome, D. Organic conductors: From charge density wave TTF-TCNQ to superconducting (TMTSF) ${ }_{2} \mathrm{PF}_{6}$. Chem. Rev. 2004, 104, 5565-5591. [CrossRef] [PubMed]

3. Saito, G.; Yoshida, Y. Development of conductive organic molecular assemblies: Organic metals, superconductors, and exotic functional materials. Bull. Chem. Soc. Jpn. 2007, 80, 1-137. [CrossRef]

4. Ishiguro, T.; Yamaji, K.; Saito, G. Organic Superconductors, 2nd ed.; Springer: Berlin, Germany, 1998.

5. Wong, J.W.L.; Mailman, A.; Lekin, K.; Winter, S.M.; Yong, W.; Zhao, J.; Garimella, S.V.; Tse, J.S.; Secco, R.A.; Desgreniers, S.; et al. Pressure induced phase transitions and metallization of a neutral radical conductor. J. Am. Chem. Soc. 2014, 136, 1070-1081. [CrossRef]

6. Tian, D.; Winter, S.M.; Mailman, A.; Wong, J.W.L.; Yong, W.; Yamaguchi, H.; Jia, Y.; Tse, J.S.; Desgreniers, S.; Secco, R.A.; et al. The metallic state in neutral radical conductors: Dimensionality, pressure and multiple orbital effects. J. Am. Chem. Soc. 2015, 137, 14136-14148. [CrossRef]

7. Souto, M.; Cui, H.B.; Peña-Álvarez, M.; Baonza, V.G.; Jeschke, H.O.; Tomic, M.; Valenti, R.; Blasi, D.; Ratera, I.; Rovira, C.; et al. Pressure-induced conductivity in a neutral nonplanar spin-localized radical. J. Am. Chem. Soc. 2016, 138, 11517-11525. [CrossRef]

8. Souto, M.; Gullo, M.C.; Cui, H.B.; Casati, N.; Montisci, F.; Jeschke, H.O.; Valenti, R.; Ratera, I.; Rovira, C.; Veciana, J. Role of the open-shell character on the pressure-induced conductivity of an organic donor-acceptor radical dyad. Chem. Eur. J. 2018, 24, 5500-5505. [CrossRef]

9. Isono, T.; Kamo, H.; Ueda, A.; Takahashi, K.; Nakao, A.; Kumai, R.; Nakao, H.; Kobayashi, K.; Murakami, Y.; Mori, H. Hydrogen bond-promoted metallic state in a purely organic single-component conductor under pressure. Nat. Commun. 2013, 4, 1344. [CrossRef] 
10. Inabe, T.; Maruyama, Y. Multi-dimensional stacking structure in phthalocyanine-based electrical conductors, $\mathrm{K}\left[\mathrm{Co} \text { (phthalocyaninato) }(\mathrm{CN})_{2}\right]_{2} \cdot 5 \mathrm{CH}_{3} \mathrm{CN}$ and $\mathrm{Co}($ phthalocyaninato $)(\mathrm{CN})_{2} \cdot 2 \mathrm{H}_{2} \mathrm{O}$. Bull. Chem. Soc. Jpn. 1990, 63, 2273-2280. [CrossRef]

11. Hasegawa, H.; Naito, T.; Inabe, T.; Akutagawa, T.; Nakamura, T. A highly conducting partially oxidized salt of axially substituted phthalocyanine. Structure and physical properties of TPP $\left[\mathrm{Co}(\mathrm{Pc})(\mathrm{CN})_{2}\right]_{2}\{\mathrm{TPP}$ = tetraphenylphosphonium, $\left[\mathrm{Co}(\mathrm{Pc})(\mathrm{CN})_{2}\right]=$ dicyano(phthalocyaninato)cobalt(III) $\}$. J. Mater. Chem. 1998, 8, 1567-1570. [CrossRef]

12. Inabe, T.; Tajima, H. Phthalocyanines-Versatile components of molecular conductors. Chem. Rev. 2004, 104, 5503-5533. [CrossRef]

13. Inabe, T. Design of functional molecular crystal by controlling intermolecular interactions. Bull. Chem. Soc. Jpn. 2005, 78, 1373-1383. [CrossRef]

14. Inabe, T.; Ishikawa, M.; Asari, T.; Hasegawa, H.; Fujita, A.; Matsumura, N.; Naito, T.; Matsuda, M.; Tajima, H. Phthalocyanine conductors: New trend for crystal and functionality design. Mol. Cryst. Liq. Cryst. 2006, 455, 87-92. [CrossRef]

15. Myers, J.F.; Canham, G.W.R.; Lever, A.B.P. Higher oxidation level phthalocyanine complexes of chromium, iron, cobalt, and zinc. Phthalocyanine radical species. Inorg. Chem. 1975, 14, 461-468. [CrossRef]

16. Yu, D.E.C. Synthesis of Axially-Ligated Metallophthalocaynine Molecular Conductors and the Chemical and Physical Factors Affecting Their Solid-State Properties. Ph.D. Thesis, Hokkaido University, Sapporo, Japan, 2008.

17. Hedtmann-Rein, C.; Hanack, M.; Peters, K.; Peters, E.-M.; Schnering, H.G. Synthesis and properties of (phthlaocyaninato) and (tetrabenzoporphyrinato)cobalt(III) thiocyanate and isothiocyanate compounds. Crystal and molecular structures of (phthalocyaninato)(pyridine)(thiocyanato)cobalt(III). Inorg. Chem. 1987, 26, 2647-2651. [CrossRef]

18. Sir 2019. Available online: http://www.ba.ic.cnr.it/softwareic/sir/ (accessed on 25 May 2020).

19. Burla, M.C.; Caliandro, R.; Carrozzini, B.; Cuocci, C.; Mallamo, M.; Mazzone, A.; Polidori, G. Crystal structure determination and refinement via SIR 2014. J. Appl. Cryst. 2015, 48, 306-309. [CrossRef]

20. Sheldrick, G.M. Crystal structure refinement with SHELXL. Acta Crystallogr. Sect. C Struct. Chem. 2015, 71, 3-8. [CrossRef]

21. Matsuda, M.; Naito, T.; Inabe, T.; Hanasaki, N.; Tajima, H.; Otsuka, T.; Awaga, K.; Narymbetov, B.; Kobayashi, H. A one-dimensional macrocyclic $\pi$-ligand conductor carrying a magnetic center. Structure and electrical, optical and magnetic properties of TPP $\left[\mathrm{Fe}(\mathrm{Pc})(\mathrm{CN})_{2}\right]_{2}\{\mathrm{TPP}=$ tetraphenylphosphonium and $\left[\mathrm{Fe}(\mathrm{Pc})(\mathrm{CN})_{2}\right]=$ dicyano(phthalocyaninato)iron(III)\}. J. Mater. Chem. 2000, 10, 631-636. [CrossRef]

22. Matsuda, M.; Naito, T.; Inabe, T.; Hanasaki, N.; Tajima, H. Structure and electrical and magnetic properties of $(\mathrm{PTMA})_{x}\left[\mathrm{M}(\mathrm{Pc})(\mathrm{CN})_{2}\right] \cdot y$ (solvent) $\left(\mathrm{PTMA}=\right.$ phenyltrimethylammonium and $\left[\mathrm{M}(\mathrm{Pc})(\mathrm{CN})_{2}\right]=$ dicyano(phthalocyaninato) $\mathrm{M}^{\mathrm{III}}$ with $\mathrm{M}=\mathrm{Co}$ and Fe). Partial oxidation by partial solvent occupation of the cation site. J. Mater. Chem. 2001, 11, 2493-2497. [CrossRef]

23. Matsuda, M.; Asari, T.; Naito, T.; Inabe, T.; Hanasaki, N.; Tajima, H. Structure and physical properties of low dimensional molecular conductors, [PXX][Fe $\left.{ }^{\mathrm{III}}(\mathrm{Pc})(\mathrm{CN})_{2}\right]$ and $[\mathrm{PXX}]\left[\mathrm{Co}^{\mathrm{III}}(\mathrm{Pc})(\mathrm{CN})_{2}\right](\mathrm{PXX}=$ peri-xanthenoxanthene, $\mathrm{Pc}_{\mathrm{c}}=$ phthalocyaninato). Bull. Chem. Soc. Jpn. 2003, 76, 1935-1940. [CrossRef]

24. Behnisch, R.; Hanack, M. Cyclic voltammetric and electrocrystallization studies of axially substituted biscyanophthalocyaninato metal complexes and related compounds. Synth. Met. 1990, 36, 387-397. [CrossRef]

25. Mori, T. Principles that govern electronic transport in organic conductors and transistors. Bull. Chem. Soc. Jpn. 2016, 89, 973-986. [CrossRef]

26. Ikeda, M.; Kanda, A.; Murakawa, H.; Matsuda, M.; Inabe, T.; Tajima, H.; Hanasaki, N. Effect of localized spin concentration on giant magnetoresistance in molecular conductors $\operatorname{TPP}\left[\mathrm{Fe}_{x} \mathrm{Co}_{1-x}(\mathrm{Pc})(\mathrm{CN})_{2}\right]_{2}$. J. Phys. Soc. Jpn. 2016, 85, 024713. [CrossRef]

27. Morimoto, K.; Inabe, T. Molecular conductors based on axially substituted phthalocyanine neutral radicals. Mol. Cryst. Liq. Cryst. 1996, 284, 291-300. [CrossRef]

(C) 2020 by the authors. Licensee MDPI, Basel, Switzerland. This article is an open access article distributed under the terms and conditions of the Creative Commons Attribution (CC BY) license (http://creativecommons.org/licenses/by/4.0/). 